\title{
Ductility of 0.1-0.6C-1.5Si-1.5Mn Ultra High-strength TRIP-aided Sheet Steels with Bainitic Ferrite Matrix
}

\author{
Koh-ichi SUGIMOTO, Michitaka TSUNEZAWA, ${ }^{1)}$ Tomohiko HOJO'1) and Shushi IKEDA ${ }^{21}$ \\ Faculty of Engineering, Shinshu University, 4-17-1, Wakasato, Nagano 380-8553 Japan. E-mail: sugimot@gipwc.shinshu-u.ac.jp \\ 1) Graduate School, Shinshu University, 4-17-1 Wakasato, Nagano 380-8553 Japan. \\ 2) Materials Research Laboratory., Kobe Steel, Ltd., 1-5-5 Takatsukadai, Nishi-ku, Kobe 651-2272 Japan.
}

(Received on March 9, 2004; accepted in final form on June 3, 2004)

\begin{abstract}
The effects of heat treatment and forming conditions on retained austenite characteristics and ductility of $0.1-0.6 \mathrm{C}-1.5 \mathrm{Si}-1.5 \mathrm{Mn}$, mass $\%$, ultra high-strength TRIP-aided sheet steels with bainitic ferrite matrix were investigated. These steels possessed large total elongations of about $20-25 \%$ in a tensile strength ranging from 700 to $1300 \mathrm{MPa}$ when austempered at temperatures above martensite-start temperature $\left(M_{\mathrm{s}}\right)$. The total elongations were enhanced by warm forming at two temperatures, $T_{\mathrm{P} 1}$ and $T_{\mathrm{P} 2}$. The first peak forming temperatures $T_{P 1} S$ were between $0^{\circ} \mathrm{C}$ and $75^{\circ} \mathrm{C}$ and were nearly constant regardless of carbon content of the steels. This was associated with the strain-induced martensite transformation of a large amount of metastable retained austenite which suppressed a rapid fall of strain-hardening rate in an early strain range to resultantly increase the uniform and total elongations. On the other hand, the second peak forming temperatures $T_{\mathrm{P} 2} \mathrm{~S}$ were between 200 and $300^{\circ} \mathrm{C}$ and further large total elongations beyond $30 \%$ were achieved in high carbon steels $(0.4 \% \mathrm{C}$ and $0.6 \% \mathrm{C}$ steels) with tensile strength of $1300-1500 \mathrm{MPa}$. The large improvement was controlled by both the strain-induced bainite transformation and dynamic strain aging.
\end{abstract}

KEY WORDS: TRIP; retained austenite; ultra high-strength steel; ductility; bainitic ferrite; warm forming.

\section{Introduction}

The transformation-induced plasticity (TRIP) ${ }^{1)}$ of retained austenite is very useful to enhance the formability of high-strength sheet steels. Thus, three kinds of low alloy TRIP-aided steels with different matrix structure and retained austenite morphology have been developed for weight reduction and impact safety performance of vehicles. The conventional TRIP-aided steels composing of polygonal ferrite matrix and blocky retained austenite and bainite islands or "TRIP-aided dual-phase (TDP) steel"2-9) possessed an excellent stretch-formability ${ }^{3)}$ and deep drawability. ${ }^{4,5)}$ However, the TDP steel has been applied to only some impact members due to a lack of stretch-flange formability and bendability.,7)

The poor stretch-flange formability and bendability of the TDP steel may be essentially overcome by replacing the ferrite matrix with bainitic ferrite matrix because the bainitic steel generally possesses an excellent stretch-flange formability due to uniform fine lath structure. On the basis of this idea, we have recently developed a new type of TRIP-aided steel or "TRIP-aided bainitic ferrite (TBF) sheet steel"10-13) composing of bainitic ferrite matrix and interlath retained austenite films. The TBF steel may be expected as an ultra high-strength steel of the next generation because it completed an excellent stretch-flange formability, ${ }^{11)}$ as well as large total elongation of about $20 \%,{ }^{10)}$ high fatigue strength ${ }^{12)}$ and good impact properties. ${ }^{13)}$
It is supposed that carbon ${ }^{14)}$ and/or manganese ${ }^{15)}$ addition into the TBF steel are effective to rise tensile strength of the TRIP-aided steels. However, there are only a few reports on the effects of carbon addition. ${ }^{16)}$ So, in the present study the effects of heat-treatment conditions on retained austenite characteristics and tensile properties of $0.1-0.6 \mathrm{C}-1.5 \mathrm{Si}-$ $1.5 \mathrm{Mn}$ TBF steels were investigated. In additon, the effects of forming temperature on the tensile properties were examined.

\section{Experimental Procedure}

In the present study, four kinds of $1.5 \mathrm{Si}-1.5 \mathrm{Mn}$ steels with different carbon content as listed in Table 1 were prepared as vacuum-melted $100 \mathrm{~kg}$ ingots followed by hot forging to produce $30 \mathrm{~mm}$ thick slabs. Hereafter, the steels are called $0.1 \mathrm{C}, 0.2 \mathrm{C}, 0.4 \mathrm{C}$ and $0.6 \mathrm{C}$, respectively. The martensite-start temperature $\left(M_{\mathrm{S}}\right)$ of the steels was estimated to be between 221 and $464^{\circ} \mathrm{C}$ by the following equation. ${ }^{17)}$

$$
\begin{aligned}
M_{\mathrm{S}}\left({ }^{\circ} \mathrm{C}\right)= & 561-474 \times C-33 \times M n-17 \times N i-17 \times C \\
& -21 \times M o
\end{aligned}
$$

where $\mathrm{C}, \mathrm{Mn}, \mathrm{Ni}, \mathrm{Cr}$ and $\mathrm{Mo}$, mass\%, are contents of individual alloying element in steels.

The slabs were reheated to $1200^{\circ} \mathrm{C}$ and then hot-rolled to $3.2 \mathrm{~mm}$ in thickness with finishing at $800^{\circ} \mathrm{C}$ followed by air-cooling to room temperature, as illustrated in Fig. 1. 
Table 1. Chemical composition (mass $\%$ ), estimated martensite start temperature $\left(M_{\mathrm{S}},{ }^{\circ} \mathrm{C}\right)$ and austempering time $\left(t_{\mathrm{A}}, \mathrm{s}\right)$ of steels used.

\begin{tabular}{c|cccccccc|c|c}
\hline stee I & $\mathrm{C}$ & $\mathrm{Si}$ & $\mathrm{Mn}$ & $\mathrm{P}$ & $\mathrm{S}$ & $\mathrm{Al}$ & 0 & $\mathrm{~N}$ & $\mathrm{M}_{\mathrm{S}}$ & $\mathrm{t}_{\mathrm{A}}$ \\
\hline $0.1 \mathrm{C}$ & 0.10 & 1.49 & 1.50 & 0.015 & 0.0012 & 0.038 & 0.0011 & 0.0020 & 464 & 100 \\
$0.2 \mathrm{C}$ & 0.20 & 1.51 & 1.51 & 0.015 & 0.0011 & 0.040 & 0.0013 & 0.0021 & 416 & 200 \\
$0.4 \mathrm{C}$ & 0.40 & 1.49 & 1.50 & 0.015 & 0.0012 & 0.045 & 0.0014 & 0.0021 & 322 & 500 \\
$0.6 \mathrm{C}$ & 0.61 & 1.50 & 1.53 & 0.015 & 0.0011 & 0.041 & 0.0006 & 0.0022 & 221 & 3000 \\
\hline
\end{tabular}

$1200^{\circ} \mathrm{C}$

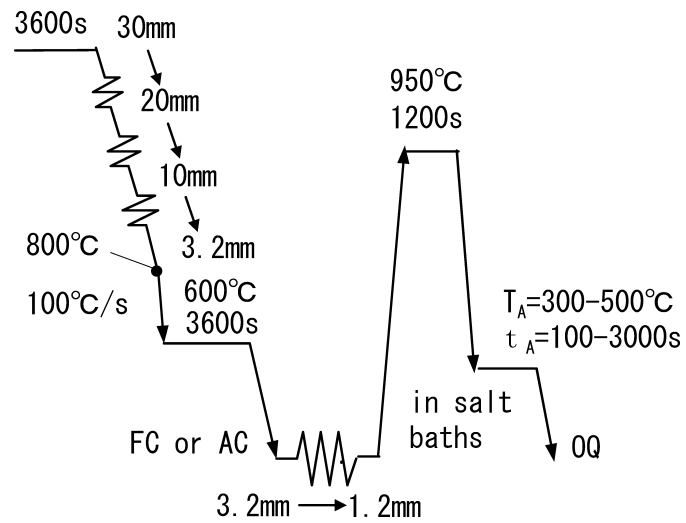

Fig. 1. Schematic diagram of hot and cold rolling process of $0.1 \mathrm{C}-0.6 \mathrm{C}$ TBF steels, in which "FC", "AC" and "OQ" represent furnace cooling, air cooling and quenching in oil, respectively.

After cold-rolling to $1.2 \mathrm{~mm}$ in thickness, they were annealed at $950^{\circ} \mathrm{C}$ for $1200 \mathrm{~s}$ and subsequently austempered at temperatures ranging from $T_{\mathrm{A}}=300$ to $500^{\circ} \mathrm{C}$ for 100 $3000 \mathrm{~s}$ in a salt bath, followed by cooling in oil to $20^{\circ} \mathrm{C}$. In this case, the austempering time to obtain both a large amount of stable retained austenite and large elongations was adopted according to the previous study ${ }^{10)}$ (see $t_{\mathrm{A}}$ in Table 1).

The amount of retained austenite was quantified by X-ray diffractometry using Mo-K $\alpha$ radiation. To minimize the effect of texture, the volume fraction of retained austenite was quantified on the basis of the integrated intensity of $(200)_{\alpha}, \quad(211)_{\alpha}, \quad(200)_{\gamma}, \quad(220)_{\gamma}$ and $(311)_{\gamma}$ diffraction peaks. ${ }^{18)}$ The retained austenite lattice constant $\left(a_{\gamma}\right)$ was measured from $(200)_{\gamma},(220)_{\gamma}$ and $(311)_{\gamma}$ diffraction peaks using $\mathrm{Cu}-\mathrm{K} \alpha$ radiation on the electrochemically polished surface with a negligible internal stress. Substituting the measured $a_{\gamma}$ value $\left(\times 10^{-1} \mathrm{~nm}\right)$ into the following equation, ${ }^{19)}$ carbon concentration of the retained austenite $\left(C_{\gamma}, \operatorname{mass} \%\right)$ was calculated.

$$
C_{\gamma}=\left(a_{\gamma}-3.578\right) / 0.033
$$

Tensile tests were carried out on an Instron type testing machine under a cross head speed of $1 \mathrm{~mm} / \mathrm{min}$ at $20^{\circ} \mathrm{C}$. Warm forming was conducted at temperatures between -50 and $400^{\circ} \mathrm{C}$.

\section{Results}

\subsection{Effects of Austempering Temperature}

Figure 2 shows austempering temperature $\left(T_{\mathrm{A}}\right)$ dependence of initial volume fraction $\left(f_{\gamma_{0}}\right)$, carbon concentration $\left(C_{\gamma 0}\right)$ and total carbon concentration $\left(f_{\gamma 0} \times C_{\gamma 0}\right)$ of retained austenite in TBF steels. It is found that the initial volume fraction of retained austenite of the $0.1 \mathrm{C}$ and $0.2 \mathrm{C}$ steels
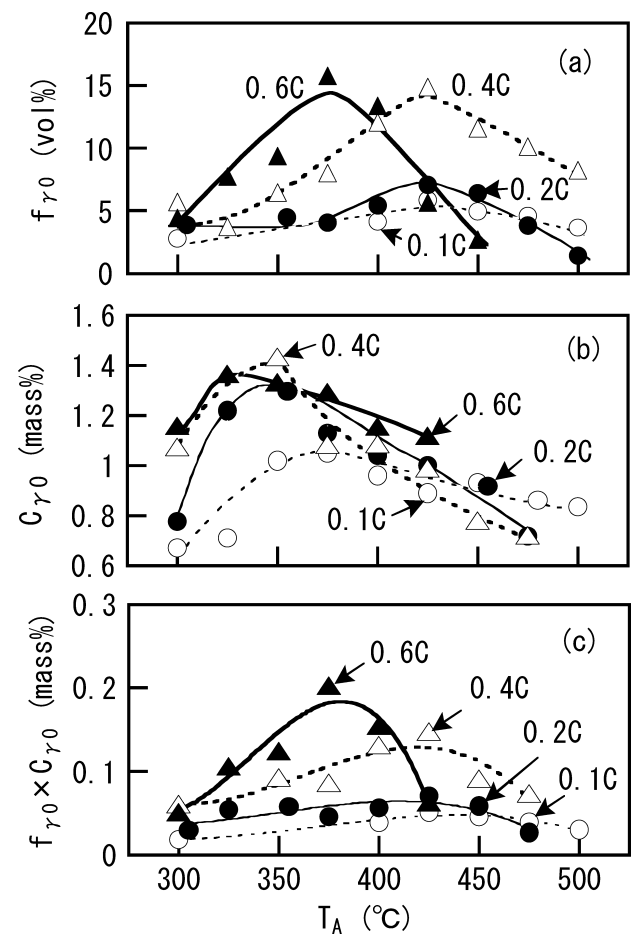

Fig. 2. Variations in (a) initial volume fraction $\left(f_{\gamma 0}\right)$, (b) initial carbon concentration $\left(C_{\gamma 0}\right)$ and (c) initial total carbon concentration $\left(f_{\gamma 0} \times C_{\gamma 0}\right)$ of retained austenite as a function of austempering temperature $\left(T_{\mathrm{A}}\right)$ in $0.1 \mathrm{C}-0.6 \mathrm{C} \mathrm{TBF}$ steels.

becomes maximum when austempered at temperatures near $M_{\mathrm{S}}$, although $0.4 \mathrm{C}$ and $0.6 \mathrm{C}$ steels possess maximum one when respectively austempered at $425^{\circ} \mathrm{C}$ and $375^{\circ} \mathrm{C}$ higher than $M_{\mathrm{S}}$ of the steels. And, it can be seen that the higher the carbon content of the steels, the larger the maximum volume fraction of retained austenite. Carbon concentration of retained austenite linearly decreases with increasing austempering temperature in a temperature range above $T_{\mathrm{A}}=350^{\circ} \mathrm{C}$. When a ratio of maximum value of total carbon concentration to added carbon content $\left(\left(f_{\gamma 0} \times C_{\gamma 0}\right) / C\right)$ was compared, the ratios are between $1 / 2$ and $1 / 3$ in $0.1 \mathrm{C}-0.6 \mathrm{C}$ steels.

Figures 3 and 4 show typical scanning and transmission electron micrographs of TBF steels, respectively. The microstructure is principally characterized by bainitic ferrite lath matrix and interlath retained austenite films (Fig. 4). If the steels have higher carbon content than $0.4 \% \mathrm{C}$, wide interlath retained austenite films or blocky retained austenite islands lie along packet boundary, block boundary and/or prior austenite grain boundary, as well as inside bainitic ferrite lath (Fig. 4(c)). And, retained austenite structure is coarsened with increasing austempering temperature and fresh martensite volume fraction is increased when austempered at temperature higher than $M_{\mathrm{S}}$.

Figure 5 shows austempering temperature dependence of 

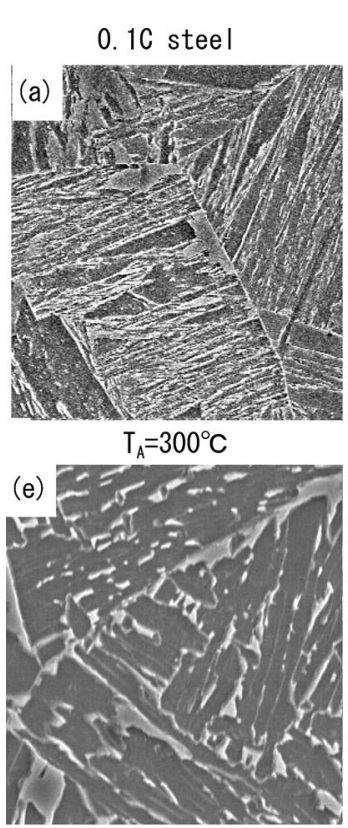

$\mathrm{T}_{\mathrm{A}}=475^{\circ} \mathrm{C}$

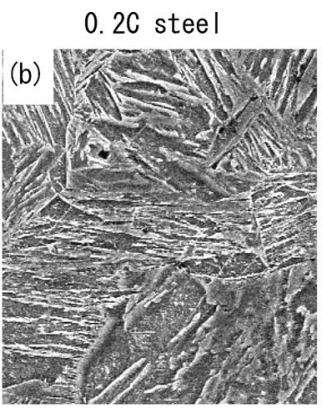

$\mathrm{T}_{\mathrm{A}}=300^{\circ} \mathrm{C}$

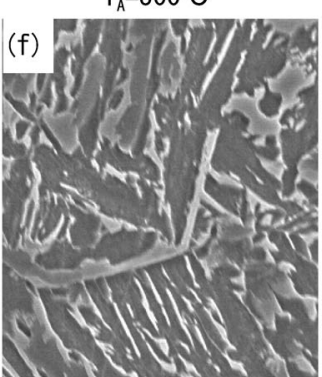

$\mathrm{T}_{\mathrm{A}}=450^{\circ} \mathrm{C}$

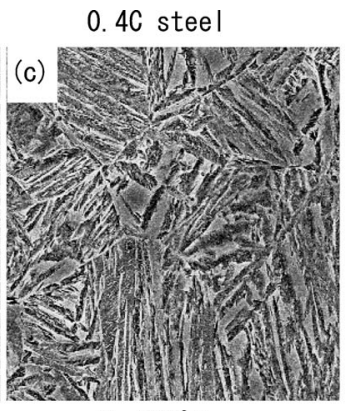

$\mathrm{T}_{\mathrm{A}}=300^{\circ} \mathrm{C}$

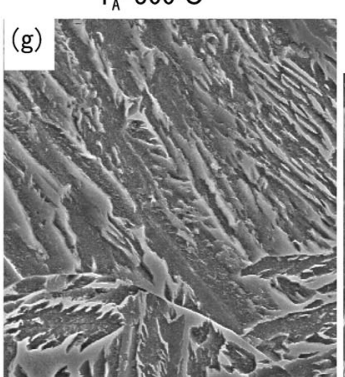

$\mathrm{T}_{\mathrm{A}}=425^{\circ} \mathrm{C}$
$0.6 \mathrm{C}$ steel

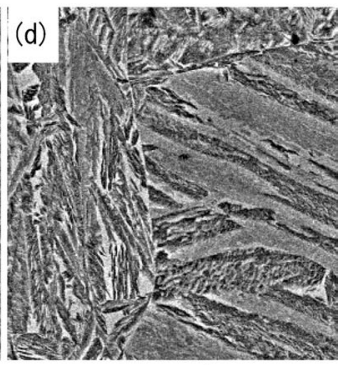

$\mathrm{T}_{\mathrm{A}}=300^{\circ} \mathrm{C}$

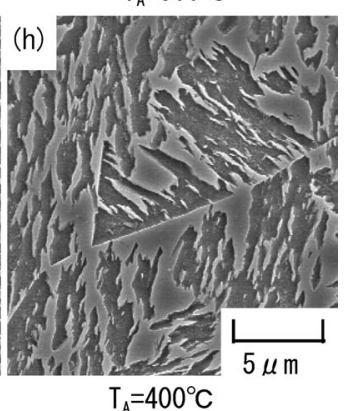

Fig. 3. Typical scanning electron micrographs of $0.1 \mathrm{C}-0.6 \mathrm{C}$ TBF steels austempered at different temperatures.
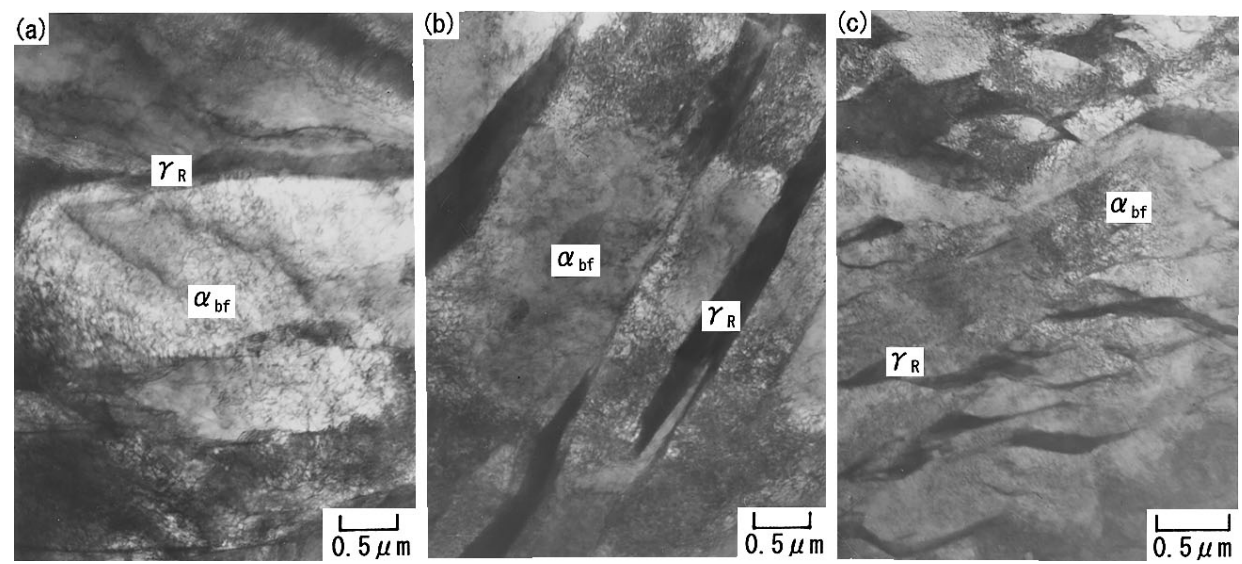

Fig. 4. Transmission electron micrographs of (a) $0.1 \mathrm{C}$, (b) $0.2 \mathrm{C}$ and (c) $0.4 \mathrm{C}$ TBF steels austempered respectively at $T_{\mathrm{A}}=475,450$ and $400^{\circ} \mathrm{C}$ in which $\gamma_{\mathrm{R}}$ and $\alpha_{\mathrm{bf}}$ represent retained austenite film and bainitic ferrite matrix, respectively.

tensile properties of $\mathrm{TBF}$ steels on testing at $T_{\mathrm{F}}=20^{\circ} \mathrm{C}$. Total elongation (TEl) and strength-ductility balance (a product of tensile strength and total elongation, $T \mathrm{~S} \times T E l)$ of the steels become maximum at the same austempering temperatures as initial volume fraction of retained austenite. The maximum total elongations are between 20 and $25 \%$. And, the higher the carbon content, the larger the strength-ductility balance. On the other hand, the tensile strength (TS) monotonously decreases with increasing austempering temperature.

\subsection{Effects of Forming Temperature}

Figure 6 shows forming temperature dependence of tensile strength $(T S)$ and total elongation $(T E l)$ of TBF steels austempered at typical temperatures. Figure 7 shows typical change in flow curve with forming temperature in $0.2 \mathrm{C}$ steel. Remarkable forming temperature dependences of total elongation and tensile strength appear in the steels, particularly in $0.4 \mathrm{C}$ and $0.6 \mathrm{C}$ steels. Maximum values of the total elongation are obtained at two forming tempera- tures, namely first peak forming temperature $T_{\mathrm{P} 1}=0-75^{\circ} \mathrm{C}$ and second peak one $T_{\mathrm{P} 2}=200-300^{\circ} \mathrm{C}$. Larger increase in total elongation is completed at the $T_{\mathrm{P} 2}$. It is noteworthy that the above forming temperature dependence of total elongation is different from that of TDP steel having only one peak forming temperature $\left(T_{\mathrm{P}}\right)$ of about $\left.100-200^{\circ} \mathrm{C} .^{2,10}\right)$

Figure 8 shows a relationship between total elongation and tensile strength (at $T_{\mathrm{F}}=20^{\circ} \mathrm{C}$ ) in $0.1-0.6 \mathrm{C} \mathrm{TBF}$ steels austempered at typical temperatures. In a tensile strength range above $1000 \mathrm{MPa}$ the TBF steels austempered at low temperatures below $350^{\circ} \mathrm{C}$ possess larger total elongation than martensitic steels. On the other hand, the TBF steels austempered at temperatures above $400^{\circ} \mathrm{C}$ achieve the similar large total elongation as TDP and DP steels when warm forming is conducted.

Generally total elongation of TDP steel is principally controlled by the strain-induced transformation behavior of retained austenite, as well as a long range internal stress. ${ }^{2,20)}$ So, the strain-induced transformation behavior was examined for $0.1 \mathrm{C}-0.6 \mathrm{C}$ TBF steels. 
Figure 9(b) shows forming temperature dependence of $k$-value or "the strain-induced transformation parameter", defined by the following equation.

$$
\log f_{\gamma}=\log f_{\gamma 0}-k \varepsilon
$$

where $f_{\gamma}$ and $f_{\gamma 0}$ represent volume fraction of retained austenite after straining and initial one, respectively. If austempered at higher temperature than $M_{\mathrm{S}}$, the TBF steels possess lower $k$-value than those austempered at $300^{\circ} \mathrm{C}$. The higher the carbon content of the steel, the lower the $k$ value. In addition, it is found that the $k$-value becomes minimum at forming temperature of $T_{\mathrm{S}}=100-150^{\circ} \mathrm{C}$.

Figure 10 shows typical transmission electron micro-
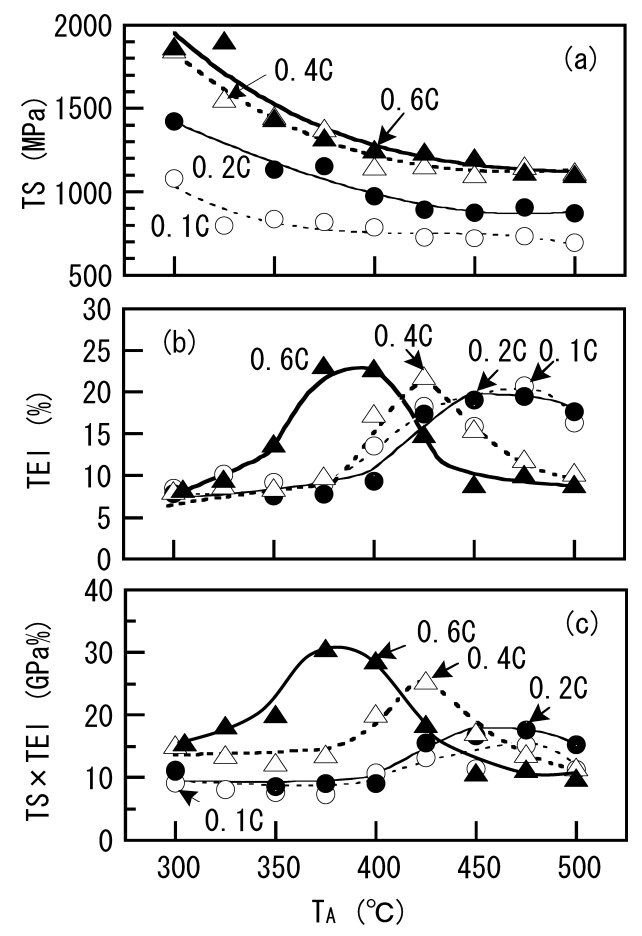

Fig. 5. Variations in (a) tensile strength $(T S)$, (b) total elongation $(T E l)$ and (c) strength-ductility balance $(T S \times T E l)$ as a function of austempering temperature $\left(T_{\mathrm{A}}\right)$ in $0.1 \mathrm{C}-0.6 \mathrm{C}$ TBF steels. Forming temperature is $T_{\mathrm{F}}=20^{\circ} \mathrm{C}$. graphs of $0.2 \mathrm{C}$ steel strained up to uniform elongation at $20^{\circ} \mathrm{C}$ or $300^{\circ} \mathrm{C}$. When strained at temperatures below the above mentioned $T_{\mathrm{S}}$, retained austenite of the steel transforms to martensite (Figs. 10(a), 10(b)). On the other hand, the retained austenite transforms to bainite or decomposes into ferrite plus cementite with a small amount of strain-induced martensite if strained at temperatures higher than $T_{\mathrm{S}}$ (Fig. 10(c)). No deformation twin was observed in the strained TBF steels, differing from the TDP steel. ${ }^{2)}$

\section{Discussion}

\subsection{Relation between Retained Austenite Characteris- tics and Carbon Content}

Takahashi and Bhadeshia ${ }^{21)}$ have proposed for carbidefree bainitic steels that the carbon concentration in retained austenite is equal to one in austenite at $T_{0}$ temperature where austenite and ferrite of the same chemical composition have identical free energies. Carbon concentration in
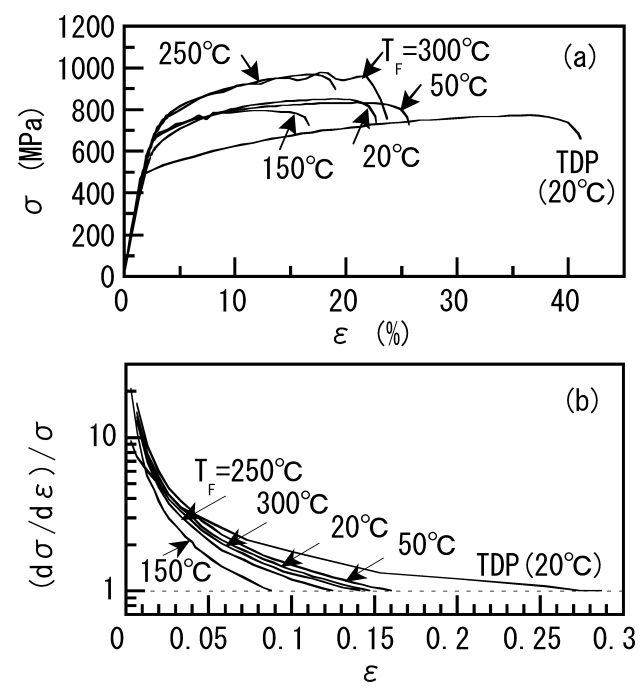

Fig. 7. Change in (a) nominal stress-strain $(\sigma-\varepsilon)$ curve and (b) normalized strain-hardening rate-true strain curve $((d \sigma / d \varepsilon) / \sigma-\varepsilon)$ with forming temperature $\left(T_{\mathrm{F}}\right)$ in $0.2 \mathrm{C}$ TBF steel austempered at $T_{\mathrm{A}}=450^{\circ} \mathrm{C}$. (a) $\mathrm{T}_{\mathrm{A}}=300^{\circ} \mathrm{C}$

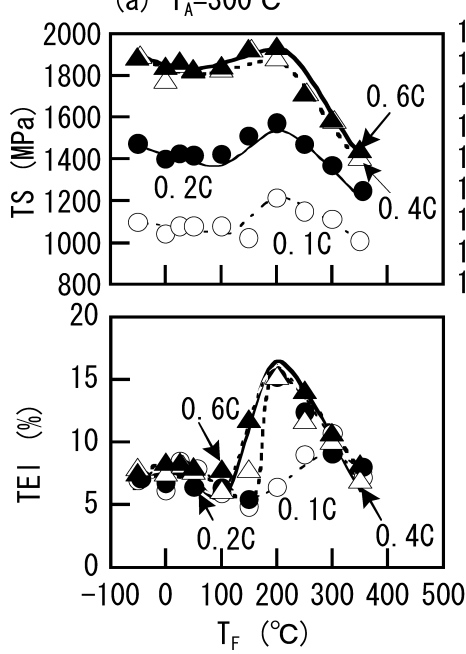

(b) $\mathrm{T}_{\mathrm{A}}=350^{\circ} \mathrm{C}$

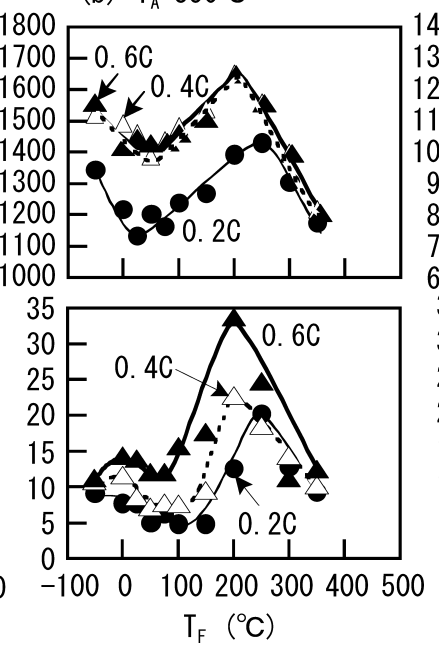

(c) $\mathrm{T}_{\mathrm{A}}=400 \sim 475^{\circ} \mathrm{C}$

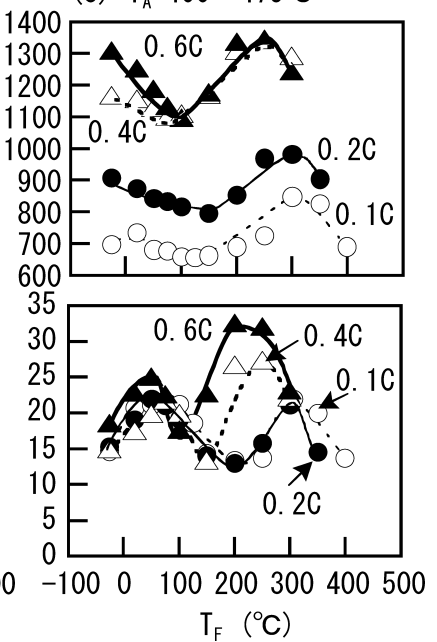

Fig. 6. Forming temperature $\left(T_{\mathrm{F}}\right)$ dependence of tensile strength $(T S)$ and total elongation $(T E l)$ in $0.1 \mathrm{C}-0.6 \mathrm{C}$ TBF steels austempered at (a) $T_{\mathrm{A}}=300$, (b) 350 or (c) $400-475^{\circ} \mathrm{C}$. In (c), $0.1 \mathrm{C}, 0.2 \mathrm{C}, 0.4 \mathrm{C}$ and $0.6 \mathrm{C}$ steels were austempered at $T_{\mathrm{A}}=475^{\circ} \mathrm{C}, 450^{\circ} \mathrm{C}, 425^{\circ} \mathrm{C}$ and $400^{\circ} \mathrm{C}$, respectively. 
austenite at $T_{0}$ temperature computed by THERMO$\mathrm{CALC}^{22)}$ is shown in Fig. 11, in which measured one in retained austenite is compared. In a temperature range above $325^{\circ} \mathrm{C}$, the temperature dependence of measured carbon concentration agrees well with that of calculated one, although the measured carbon concentrations are just lower than calculated ones. The same tendency had been also reported for TDP steel. ${ }^{20)}$ However, the carbon concentrations of $0.1 \mathrm{C}-0.6 \mathrm{C}$ TBF steels are higher than those of the TDP steel. This is because the TBF steels are characterized by carbide-free and resultantly solute carbon is effectively enriched in retained austenite.

The $0.1 \mathrm{C}$ steel possessed relatively lower carbon concentration of retained austenite than other steels, in particular when austempered at temperatures below $325^{\circ} \mathrm{C}$. This may be associated with low carbon content which leads to easy martensite transformation during cooling just after austempering.

\subsection{Controlling Factor of Ductility}

As shown in Fig. 5, total elongation and strength-ductility balance of the present TBF steels became the maximum when austempered at temperatures higher than or equal to $M_{\mathrm{S}}$. And, the higher the carbon content of steels the larger

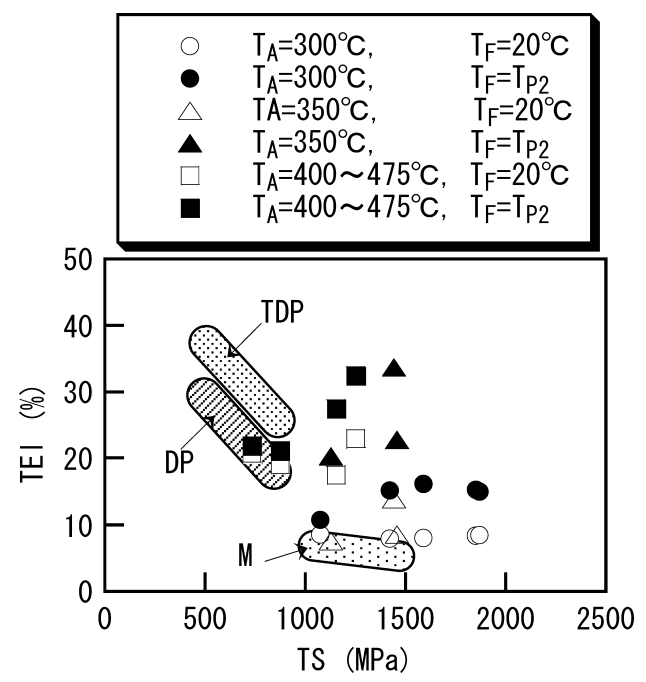

Fig. 8. Relation between total elongation $(T E l)$ and tensile strength $(T S)$ of $0.1 \mathrm{C}-0.6 \mathrm{C}$ TBF steels, in which "TDP", "DP" and "M" represent TRIP-aided dual-phase steel, ferrite-martensite dual-phase steel and martensitic steel, respectively. Solid marks denote total elongations at $T_{\mathrm{F}}=T_{\mathrm{P} 2}$ and open marks show ones at $T_{\mathrm{F}}=20^{\circ} \mathrm{C}$. the maximum values of total elongation and strength-ductility balance.

As seen in Fig. 12, the strength-ductility balance of the present TBF steels was highly correlated to volume fraction of retained austenite rather than the carbon concentration. So, the large strength-ductility balance may be completed by significant TRIP effect due to a large amount of retained austenite, which suppresses a rapid fall of strain hardening rate in a small strain range and resultantly increases uniform elongation, as shown in Fig. 7. In this case, a long range internal stress referring to second phase may increase the strength-ductility balance. However, the contribution is considered to be far smaller than in a case of TDP steel ${ }^{11)}$ because a difference in flow stress between matrix and second phase is relatively small.

\subsection{Peak Forming Temperatures}

As shown in Fig. 6, total elongations of the present TBF
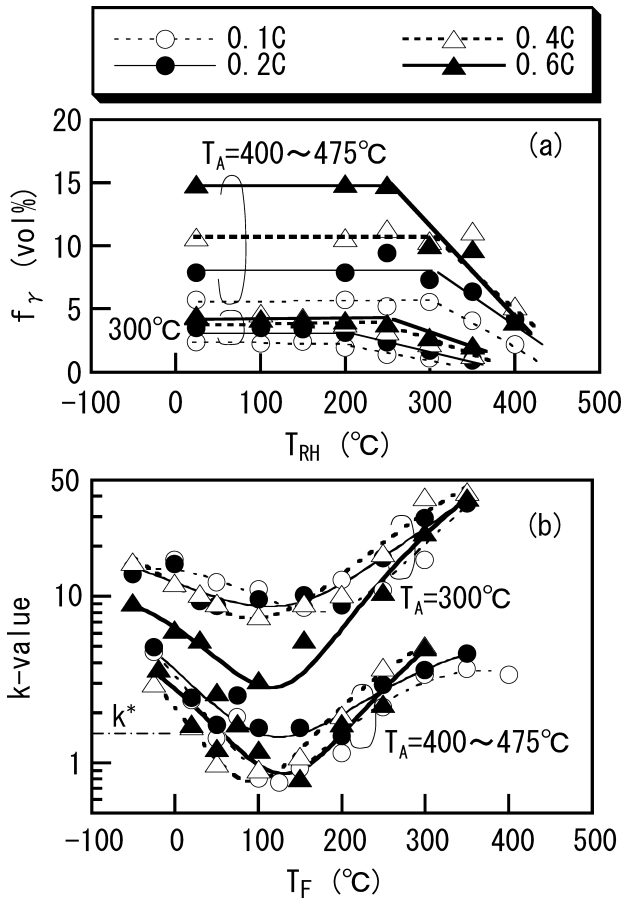

Fig. 9. (a) Reheating temperature $\left(T_{\mathrm{RH}}\right)$ dependence of retained austenite content $\left(f_{\gamma}\right)$ and (b) forming temperature $\left(T_{\mathrm{F}}\right)$ dependence of $k$-value in $0.1 \mathrm{C}-0.6 \mathrm{C}$ TBF steels austempered at $T_{\mathrm{A}}=300^{\circ} \mathrm{C}$ or $400-475^{\circ} \mathrm{C}$ in which $0.1 \mathrm{C}, 0.2 \mathrm{C}$, $0.4 \mathrm{C}$ and $0.6 \mathrm{C}$ steels were austempered at $T_{\mathrm{A}}=475^{\circ} \mathrm{C}$, $450^{\circ} \mathrm{C}, 425^{\circ} \mathrm{C}$ and $400^{\circ} \mathrm{C}$, respectively.
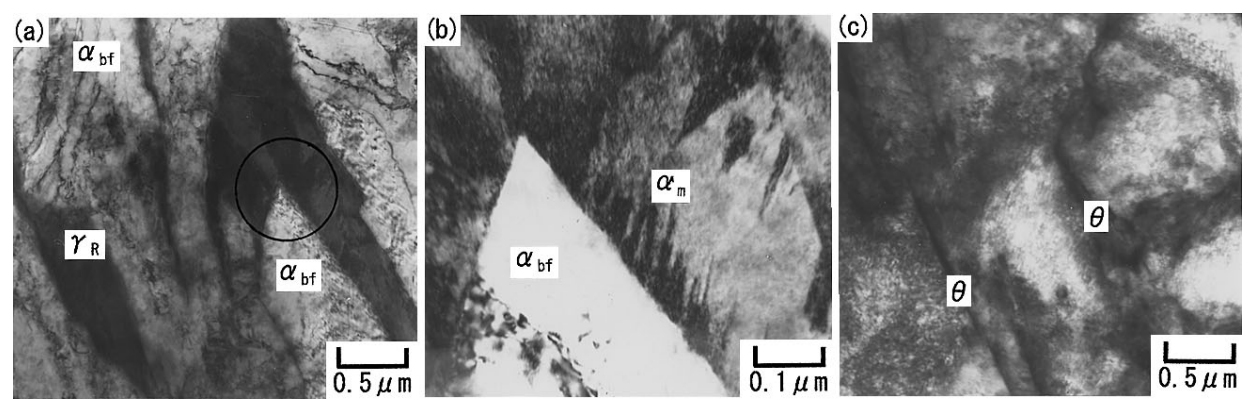

Fig. 10. Typical transmission electron micrographs of $0.2 \mathrm{C} \mathrm{TBF}$ steel deformed to uniform strain at $(\mathrm{a}, \mathrm{b}) T_{\mathrm{F}}=20^{\circ} \mathrm{C}$ or (c) $300^{\circ} \mathrm{C}$ in which $\gamma_{\mathrm{R}}, \alpha_{\mathrm{bf}}, \alpha_{\mathrm{m}}$ and $\theta$ represent retained austenite film, bainitic ferrite matrix, transformed martensite and cementite, respectively. (b) is high magnification of encircled region in (a). 


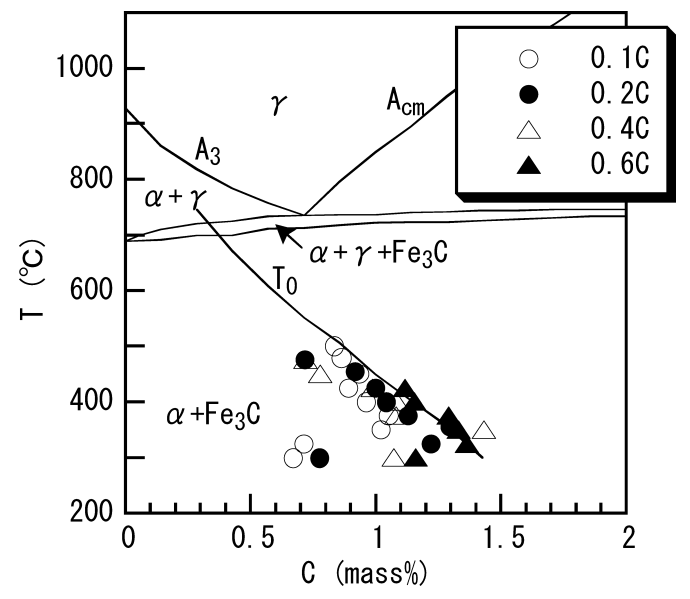

Fig. 11. Equilibrium diagram computed by Thermo-Calc. ${ }^{22)}$ and measured carbon concentration of retained austenite in $\mathrm{Fe}-\mathrm{C}-1.5 \mathrm{Si}-1.5 \mathrm{Mn}$ systems.
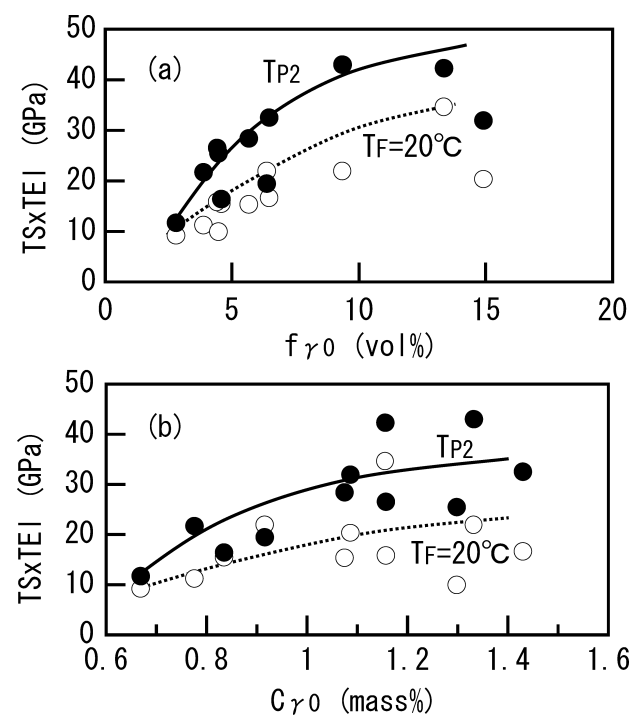

Fig. 12. Relationships between strength-ductility balance $(T S \times T E l)$ at $T_{\mathrm{F}}=T_{\mathrm{P} 2}$ or $20^{\circ} \mathrm{C}$ and (a) initial volume fraction $\left(f_{\gamma_{0}}\right)$ and (b) initial carbon concentration $\left(C_{\gamma_{0}}\right)$ of retained austenite in $0.1 \mathrm{C}-0.6 \mathrm{C}$ TBF steels austempered at $T_{\mathrm{A}}=300,350$ or $400-475^{\circ} \mathrm{C}$.

steels were enhanced at two peak forming temperatures, $T_{\mathrm{P} 1}$ and $T_{\mathrm{P} 2}$. In this section, the reason and mechanism are mentioned.

According to the previous study, ${ }^{20)}$ only one peak forming temperature appeared for total elongation in TDP steel (see $T_{\mathrm{P}}$ in Fig. 13(a)). The peak forming temperature rose with increasing $M_{\mathrm{S}}$ of retained austenite and agreed well with $T_{\mathrm{S}}$ corresponding to minimum $k$-value or forming temperature $\left(T_{\mathrm{S}}^{*}\right)$ referring to $k=1.5^{20)}$ (Fig. 13(b)). In this study, $k$-value of the TBF steels became minimum at forming temperature of $T_{\mathrm{S}}=100-150^{\circ} \mathrm{C}$ (Fig. 9(b)). Most of the retained austenites transformed to martensite during straining at temperatures lower than $T_{\mathrm{S}}$. Since the first peak forming temperature $T_{\mathrm{P} 1}$ is lower than the $T_{\mathrm{S}}$ and $k$-value at the $T_{\mathrm{P} 1}$ is higher than 1.5 , it can be considered that large total elongation at the $T_{\mathrm{P} 1}$ is controlled by TRIP effect due to the strain-induced martensite transformation (SIMT). The forming temperature dependences of $k$-value and total elongation are schematically illustrated in Fig. 13. As shown in
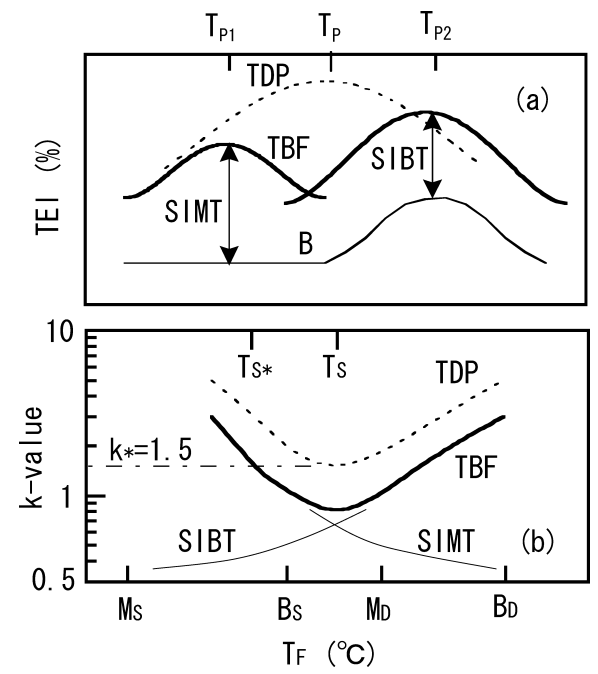

Fig. 13. Illustration of forming temperature $\left(T_{\mathrm{F}}\right)$ dependence of total elongation $(T E l)$ and $k$-value of TBF, TDP and bainitic (B) steels, in which "SIMT" and "SIBT" mean strain-induced martensite transformation and strain-induced bainite transformation, respectively. $M_{\mathrm{S}}$ and $B_{\mathrm{S}}$ are martensite-start and bainite-start temperatures of retained austenite, respectively. And $M_{\mathrm{D}}$ and $B_{\mathrm{D}}$ represent maximum temperatures at which martensite and bainite grow under influence of stress, respectively.

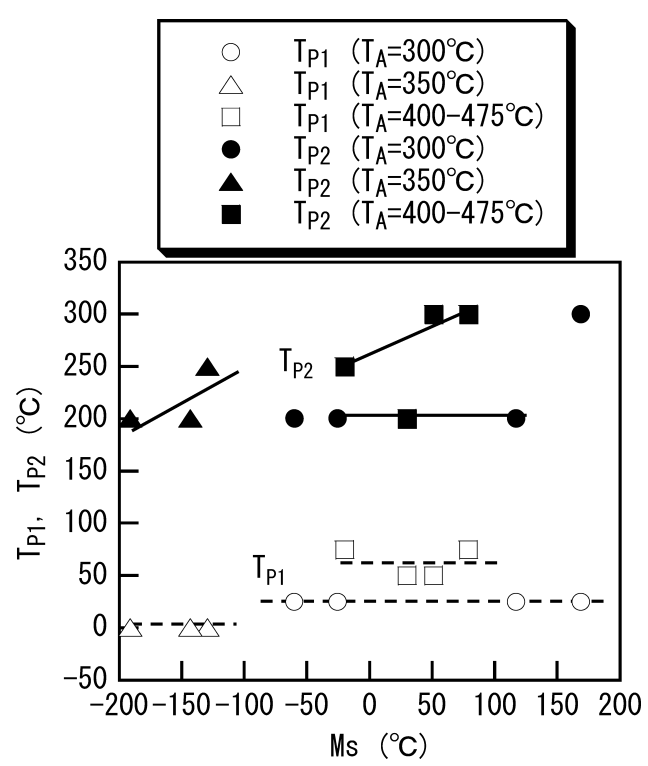

Fig. 14. Relationships between peak forming temperatures $\left(T_{\mathrm{P} 1}\right.$, $\left.T_{\mathrm{P} 2}\right)$ and martensite-start temperature $\left(M_{\mathrm{S}}\right)$ of retained austenite in $0.1 \mathrm{C}-0.6 \mathrm{C}$ TBF steels.

Fig. 14, $T_{\mathrm{P} 1}$ of the present TBF steels was independent on carbon concentration or $M_{\mathrm{S}}$ of retained austenite. The reason is not clear.

Next, let us discuss about the second peak forming temperature, $T_{\mathrm{P} 2}$. Fig. 9(a) represents that retained austenite decomposes into ferrite and cementite by only reheating at temperatures above $200-300^{\circ} \mathrm{C}$ for $3600 \mathrm{~s}$. Also, it was observed that the retained austenite transformed to bainite during forming at the $T_{\mathrm{P} 2}$ (Fig. 10(c)). Therefore, a significant increase in total elongation at the $T_{\mathrm{P} 2}$ may be controlled by TRIP effect referring to the strain-induced bainite transformation (SIBT), differing from a case at the $T_{\mathrm{P} 1}$. Also, dynamic strain aging may enhance the total elonga- 
tion through an increase in strain-hardening rate, because moderate serrations and increased flow stress were observed in the flow curves at the $T_{\mathrm{P} 2}$ (Fig. 7(a)) and the same behavior appeared even in bainitic steel (B steel) without retained austenite (Fig. 13(a)). The $T_{\mathrm{P} 2}$ tends to increase with increasing $M_{\mathrm{S}}$ of retained austenite (or decreasing carbon content of steel), as shown in Fig. 14. This may be because the decomposition start temperature of retained austenite (Fig. 9(a)) increases with increasing $M_{\mathrm{S}}$ of retained austenite.

\section{Conclusions}

The effects of austempering temperature and forming temperature on retained austenite characteristics and ductility of $0.1-0.6 \mathrm{C}-1.5 \mathrm{Si}-1.5 \mathrm{Mn}$, mass $\%$, TBF steels were investigated. The results are summarized as follows.

(1) Volume fraction and carbon concentration of retained austenite were increased with increasing carbon content in the TBF steels. Most of the retained austenite lay along bainitic ferrite lath boundary. However, if the TBF steels with 0.4 or 0.6 mass $\%$ carbon were austempered at temperatures above $M_{\mathrm{S}}$, coarse blocky retained austenite islands were recognized along their block, packet and/or prior austenitic grain boundaries, as well as a large amount of fresh martensite.

(2) When austempered at temperatures above $M_{\mathrm{S}}$, the TBF steels possessed large total elongations of about $20-25 \%$ at maximum. The higher the carbon content of the steels, the larger the total elongation and the lower the optimum austempering temperature.

(3) Total elongations of the steels were enhanced at two forming temperatures. The first peak forming temperature $T_{\mathrm{P} 1}$ was between 0 and $75^{\circ} \mathrm{C}$ and total elongation was mainly increased due to the strain-induced martensite transformation, particularly in the steels austempered at temperatures above $M_{\mathrm{S}}$. The second peak forming temperature $T_{\mathrm{P} 2}$ was between 200 and $300^{\circ} \mathrm{C}$, and extreme large total elongations beyond $30 \%$ were achieved at the $T_{\mathrm{P} 2}$. This was mainly controlled by the strain-induced bainite transformation and dynamic strain aging.

The authors gratefully acknowledge financial support by grants from The Iron and Steel Institute of Japan (2004) and Amada Foundation for Metal Work Technology (AF2003016). A part of this study was supported by the Grantin-Aid for Scientific Research (C), The Ministry of Education, Science, Sports and Culture, Japan (No. 200415560624).

\section{REFERENCES}

1) V. F. Zackay, E. R. Parker, D. Fahr and R. Bush: Trans. Am. Soc. Met., 60 (1967), 252.

2) K. Sugimoto, M. Kobayashi and S. Hashimoto: Metall. Trans. A, 23A (1992), 3085.

3) K. Sugimoto, M. Kobayashi A. Nagasaka and S. Hashimoto: ISIJ Int., 35 (1995), 1407.

4) S. Hiwatashi, M. Takahashi, T. Katayama and M. Usuda: J. Jpn. Soc. Technol. Plast., 35 (1994), 1109.

5) O. Matsumura, Y. Sakuma, Y. Ishii and J. Zhao: ISIJ Int., 32 (1992), 1110 .

6) Y. Hirose, S. Nakai, H. Furuyama, S. Sudoh and K. Ueno: J. Jpn. Soc. Technol. Plast., 35 (1994), 1071.

7) A. Nagasaka, K. Sugimoto, M. Kobayashi and S. Hashimoto: Tetsuto-Hagané, 83 (1997), 335.

8) Z. Hanzaki, P. D. Hodgson and S. Yue: ISIJ Int., 35 (1995), 79.

9) P. Jacqes, K. Eberle, P. Harlet and F. Delannay: Proc. 40th Mech. Work. Steel Processing Conf., ISS, Warrendale, PA, (1998), 239.

10) K. Sugimoto, T. Iida, J. Sakaguchi and T. Kashima: ISIJ Int., 40 (2000), 902.

11) K. Sugimoto, J. Sakaguchi, T. Iida and T. Kashima: ISIJ Int., 40 (2000), 920.

12) K. Sugimoto, M. Kobayashi, K. Inoue and Y. Masuda: Tetsu-toHagané, 85 (1999), 856.

13) S. Song, K. Sugimoto, M. Kobayashi, H. Matsubara and T. Kashima: Tetsu-to-Hagané, 86 (2000), 563.

14) K. Sugimoto, A. Kanda, R. Kikuchi, S. Hashimoto, T. Kashima and S. Ikeda: ISIJ Int., 42 (2002), 910.

15) K. Sugimoto, K. Nakano, S. Song and T. Kashima: ISIJ Int., 42 (2002), 450.

16) K. Shinoda and T. Yamada: J. Jpn. Soc. Heat Treat., 20 (1980), 326.

17) W. Steven and A. G. Haynes: J. Iron Steel Inst., 183 (1956), 349.

18) H. Maruyama: J. Jpn. Soc. Heat Treat., 17 (1977), 198.

19) D. J. Dyson and B. Holmes: J. Iron Steel Inst., 208 (1970), 469.

20) K. Sugimoto, N. Usui, M. Kobayashi and S. Hashimoto: ISIJ Int., 32 (1992), 1311.

21) M. Takahashi and H. K. D. Bhadeshia: Mater. Trans., JIM, 32 (1991), 689.

22) B. Sundman, B. Janssen and J. O. Andersson: Calphad, 9 (1985), 153. 